\title{
Importance of bees in pollination of Solanum lycopersicum L. (Solanaceae) in open-field of the Southeast of Minas Gerais State, Brazil
}

\author{
Ronaldo Vinícius-Silva ${ }^{1,3}$, Daniele de Freitas Parma ${ }^{1}$, Renata Barreto Tostes ${ }^{2}$, Viviane Modesto Arruda ${ }^{2}$ and \\ Margarete do Valle Werneck ${ }^{2}$
}

Received: 8.02.2017; accepted: 8.05.2017

\begin{abstract}
Importance of bees in pollination of Solanum lycopersicum L. (Solanaceae) in open-field of the Southeast of Minas Gerais State, Brazil). Pollinators are extremely important in agricultural crops because their deficit can affect food production in the world. Consequently, a lot of studies have been emphasizing the importance of the knowledge about the biology of these agents. The tomato stands out among the economically most important crops. Therefore, the objectives of this work were: to identify the pollinators of Solanum lycopersicum in a conventional area of cultivation in the southeast of Minas Gerais State and detect which of these are more representative; to assess the importance of the pollinators' action for the quality of the fruits produced; and discuss practices for conservation to these agents. Fifteen floral visitors were found, with Exomalopsis analis being the most representative. Apis mellifera and Trigona spinipes, although not vibrating bees, also acted as pollinators of Solanum lycopersicum.
\end{abstract}

Keywords: buzz pollination, conventional cultivation, environmental services

RESUMO - (Importância das abelhas na polinização de Solanum lycopersicum L. (Solanaceae) em cultivo aberto no Sudeste do Estado de Minas Gerais, Brasil). Polinizadores são extremamente importantes em cultivos agrícolas, pois o seu déficit pode afetar a produção de alimentos no mundo. Sendo assim, estudos têm enfatizado a importância do conhecimento sobre a biologia desses agentes. Dentre as espécies olerícolas mais importantes economicamente, destaca-se o tomate. Assim, este estudo objetivou identificar os potenciais polinizadores de Solanum lycopersicum em uma área de cultivo convencional no sudeste do Estado de Minas Gerais; identificar quais destes são mais representativos, verificar a importância da sua ação na qualidade dos frutos produzidos e discutir práticas para a conservação desses agentes. Foram encontrados 15 visitantes florais, sendo Exomalopsis analis o mais representativo. Apis mellifera e Trigona spinipes, mesmo não sendo abelhas vibradoras, também atuaram como polinizadores de Solanum lycopersicum.

Palavras-chave: buzz pollination, cultivo convencional, serviço ambiental

\section{Introduction}

The pollinators' action is extremely important in agricultural crops, being directly or indirectly responsible for about $1 / 3$ of the food production consumed by humans worldwide (Klein et al. 2007, Ollerton et al. 2011). In this context, $73 \%$ of cultivated species relies on the action of the bees for pollination. Their action can influence the quality of fruits and seeds produced (FAO 2004), increase productivity (MalagodiBraga 2002), as well as to standardize fruit ripening, which hence avoids crop losses (Willians et al. 1991).

In general, the number of pollinating guild species has declined alarmingly and the main causes are related with agricultural intensification, including the use of agrochemicals (Pinheiro \& Freitas 2010) and the fragmentation of native areas (Freitas et al. 2009). The fragmentation causes habitats heterogeneity and contributes to changes in the diversity of pollinators (Benton et al. 2003).

The pollination deficit can affect food production around the world and this issue emphasizes the importance of knowing the pollinators powers, mainly bees, of cultivated plants (Hein 2009). Considering the decline of pollinators, conserving these agents is necessary, however, some data associated to richness, taxonomy, diversity and distribution of these agents still need to be better investigated.

1. Universidade Federal de Viçosa, Departamento de Biologia Vegetal, Av. Purdue s/n., 36570-900 Viçosa, Minas Gerais, Brasil

2. Universidade do Estado de Minas Gerais, Departamento de Ciências Biológicas, Rua Olegário Maciel, 1427, 36500-000 Ubá, Minas Gerais, Brasil

3. Corresponding author: ronaldovinybio@yahoo.com.br 
In this aspect, projects as the International Pollinators Initiative and the Brazilian Pollinators Initiative have been gathering information that can help conserving these agents (Imperatriz-Fonseca et al. 2007, Freitas et al. 2009). Studies have shown that the presence of fragments of native vegetation near crops has increased the reproductive success of cultivated species (Kremen et al. 2002, Klein et al. 2003, Holzschuh et al. 2012). This is because these fragments provide resources and nesting sites for insects, especially bees (Liow et al. 2001).

In planting areas, knowledge about interactions between crops and their pollinators, on a local scale, is important to propose management and protection actions to these agents (Klein et al. 2003). Studies of this nature are relevant because this kind of information is still incipient and restricted to few cultures and regions (Yamamoto et al. 2010).

Among the most important cultivated species, we emphasize the tomato, Solanum lycopersicum L. (Solanaceae), produced on a large scale, both at national level (Filgueiras 2008) and worldwide (FAO 2009). Its flowers are hermaphrodite and selfpollinated, however, their anthers need to be vibrated to release the pollen grains that will reach the stigma (Buchmann 1983). This vibration can be performed by vibrating bees in a type of pollination known as buzz pollination (Buchmann 1983) or by the action of the wind (Del Sarto et al. 2004).

Most of the studies upon pollination in Solanum lycopersicum were conducted in greenhouse. In these studies, the main species of bees considered to be pollinators were those of the genera Bombus (Dogterom et al. 1998, Velthuis 2002, MalagodiBraga 2005, Palma et al. 2007, Vergara \& FonsecaBuendía 2012), Melipona (Del Sarto et al. 2005, Bispo dos Santos et al. 2009, Nunes-Silva et al. 2010), Nanotrigona (Cauch et al. 2004, Palma et al. 2007) and Xylocopa (Velthuis 2002). In addition, there are few studies upon the open field (Macias-Macias et al. 2009, Santos \& Nascimento 2011, Silva-Neto et al. 2013, Silva-Neto et al. 2016).

This research aims to identify potential pollinators of Solanum lycopersicum in a conventional crop in the southeast Minas Gerais State, as well as to identify which of these are more representative. In addition, we verified the importance of these agents to the quality of the fruits produced and discussed some practices to preserve these pollinators.

\section{Material and methods}

Study area - The study was conducted in a conventional cropping of tomato Salad type, at Guiricema city, southeast of Minas Gerais (figure 1). The region is marked by an average annual temperature of $23.5^{\circ} \mathrm{C}$; rainfall to $1,567 \mathrm{~mm} /$ year and Cwa climate, according to Köppen's classification, characterized by dry winters and rainy summers (Climate-Data 2016).

The crop was located at Fazenda Boa Vista $\left(21^{\circ} 01^{\prime} 05^{\prime \prime} \mathrm{S}, 42^{\circ} 38^{\prime} 23^{\prime \prime} \mathrm{W}\right)$. In the surrounding area, there were two fragments of native forest distant, 200 and $600 \mathrm{~m}$ of the crop, and two other cultures, passion fruit (Passiflora edulis Sims) and okra (Abelmoschus esculentus (L.) Moench). However, most of the farming environment consisted of pasture.

The culture was conducted based on traditional techniques, using the grafting system. The crop was periodically exposed to the appliance of pesticide and watering, with the pesticide being launched twice a week, late in the afternoon, when pollinators were no longer foraging and irrigation was done every two days.
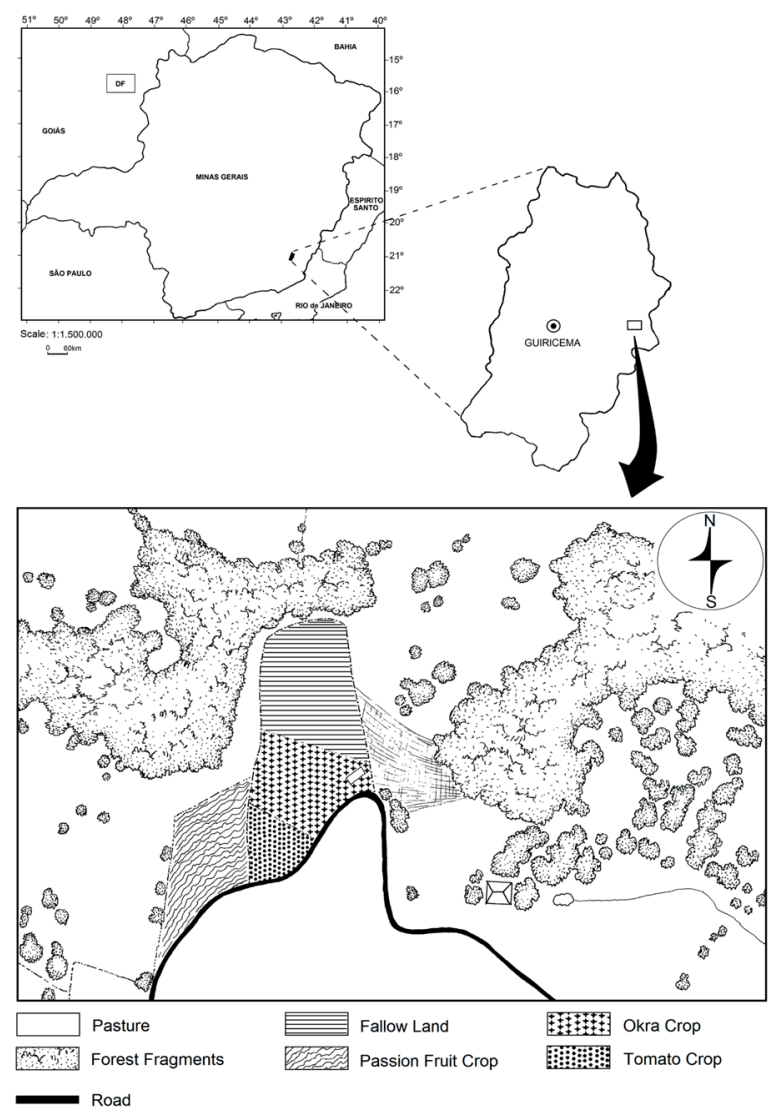

Figure 1. Map of study area showing site surrounded by other crops and forest fragments, located in the municipality of Guiricema, Minas Gerais State, Brazil. 
Richness, behavior and representativeness of floral visitors - Sampling of floral visitors was carried out in the periods of June-August 2011 and June-August 2012. This procedure was conducted via active collection, in which, during the flowering period, the crop was randomly ranged from 10 a.m. to 2 p.m. Along the way, the bees foraging on tomato flowers were collected with the aid of a hand net. This capture was conducted over 10 days in the cultivation of 2011 and 10 days in the cultivation of 2012, totaling an 80 hours sample effort. Samples of collected visitors were assembled, duly tagged and identified. The vouchers were deposited in the Entomological Collection of the Taxonomic Collections of the Universidade Federal de Minas Gerais.

The frequency of floral visitors was verified through observations, performed between 8 a.m and 5 p.m on each day, for ten minutes each hour. This procedure was repeated for ten days in cultivation in 2011 and ten days in cultivation in 2012, amounting 34 hours. During regular observations, the behavior of the floral visitors was also noted. In addition, hourlyrelated temperature data were collected every day of analysis.

Pollination testing - Two experiments were conducted: 1) Open pollination - The flowers were marked with a ribbon and left exposed to the action of the pollinators and 2) Self-pollination - The flowers were bagged with organza at the pre-anthesis phase, to avoid contact with the floral visitors.

The open pollination was conducted with 100 flowers of the different individuals and self-pollination in another 100 flowers of the different individuals. In each year, 2011 and 2012, 50 individuals were used for the open pollination experiment and 50 for the selfpollination experiment, amounting 200 individuals observed.

The evaluation of the quality of the fruit was conducted with tomatoes produced in each of the above experiments. However, some fruits from bagged flowers aborted in the initial development stage and cannot be analyzed. Thus, in total were analyzed 100 tomatoes from marked flowers and 58 tomatoes from bagged flowers.

This evaluation was performed from the weight, verified with analytical balance and the number of seeds produced, which were removed from the fruits, transferred to petri dishes, oven dried and after manually quantified. All these measurements were carried out at the Biological Sciences Laboratory of the Universidade do Estado de Minas Gerais - Campus Ubá,

Statistical analysis - Data were tabulated using the descriptive statistical analysis. A significance level of 5\% was adopted. For the data analysis, Pearson correlation was used to measure the degree of linear relationship between temperature and frequency of floral visitors and t-test for independent samples to compare the fruiting data from the different pollination treatments. In addition, we used the Shannon diversity index (H') to compare the diversity of each year of collection and the Sorensen similarity index (ISS) representing the common species between the two communities, allowing the evaluation of the similarity between the years sampled. Subsequently, the paired t-test was used.

For the calculation of the diversity index of Shannon, we use the formula below:

$$
\mathrm{H}^{\prime}=-\sum p i \cdot \ln p i
$$

Where: $p i=$ ni/N, ni: number of individuals of species $\mathrm{i}$; N: total number of individuals sampled; ln: neperian logarithm.

For the calculation of Sorensen's similarity index, we use the formula below:

$$
\mathrm{ISS}=(2 . \mathrm{C}) /(\mathrm{S} 1+\mathrm{S} 2)
$$

Where: C - number of common species in two years; S1- number of community species in 2011; S2 number of community species in 2012 .

\section{Results and Discussion}

Richness, behavior and representativeness of floral visitors - During the observation period, the bees were the only pollinators of Solanum lycopersicum. Fifteen species were cataloged in the studied area belonging to the families Andrenidae, Apidae and Halictidae (table 1). All individuals collected were females and Apidae was the family with the highest species richness. Among all the species collected, nine perform the buzz pollination, typical pollination of flowers that have poricidal anthers and that requires vibration to release the pollen.

The flowers analyzed presented rimosas anthers (figure 2a), different from those observed by other authors (e.g. Buchmann 1983, Plowright \& Laverty 1987). These anthers are collapsible, constituting a cone-shaped structure that has a pore at its apex (figure $2 b)$. Thus, the rimosas anthers, when united in cone, began to show equivalence with a single and large poricidal anther. 
Table 1. Floral visitors of Solanum lycopersicum and their representativeness observed in an open-field area in Guiricema, Minas Gerais State, Brazil, during the years 2011 and 2012. (*): species that perform buzz pollination.

\begin{tabular}{lll}
\hline & \multicolumn{2}{c}{ Representativeness } \\
\cline { 2 - 3 } Species & 2011 & 2012 \\
\hline Andrenidae & 0.005 & 0.000 \\
$\quad$ Oxaea flavescens (Klug 1807)* & & \\
Apidae & 0.307 & 0.289 \\
Apis mellifera (Linnaeus 1758) & 0.025 & 0.022 \\
Bombus (Fervidobombus) morio (Swederus 1787)* & 0.012 & 0.000 \\
Bombus (Fervidobombus) pauloensis (Friese 1913)* & 0.356 & 0.375 \\
Exomalopsis (Exomalopsis) analis (Spinola 1853)* & 0.010 & 0.000 \\
Exomalopsis (Exomalopsis) fulvofasciata (Smith 1879)* & 0.053 & 0.051 \\
Thygater (Thygater) analis (Lepeletier 1841)* & 0.043 & 0.042 \\
Trigona spinipes (Fabricius 1793) & 0.005 & 0.005 \\
Plebeia sp. & & \\
Halictidae & 0.030 & 0.042 \\
Augochloropsis callichroa (Cockerell 1900)* & 0.043 & 0.031 \\
Augochloropsis electra (Smith 1853)* & 0.020 & 0.031 \\
Augochloropsis smithiana (Cockerell 1900)* & 0.017 & 0.000 \\
Augochloropsis sp.* & 0.043 & 0.034 \\
Pseudaugochlora erythrogaster (Almeida 2008)* & 0.025 & 0.045 \\
Pseudaugochlora graminea (Fabricius 1804)* & & \\
\hline
\end{tabular}

The vibrating bees were attached to the anthers cone by their jaws and placed below the apical pore (figure 2c), because the flowers of Solanum lycopersicum were pendant. These species, when vibrating their structure released the pollen from the anthers that came out of the cone through the apical pore. Subsequently, they cleaned and stored the pollen in their corbiculas.

Through Pearson's correlation, we observed a moderate positive correlation $(64.4 \%)$ between the temperature and the frequency of floral visitors. Thus, these bees more frequently foraged in the period between 11 a.m and 3 p.m, time with the higher temperatures (figure 3). These data are consistent with Burril \& Dietz (1981), who mention that the flight of the bees can be inhibited at low temperatures. This process occurs mainly in solitary bees (most of the species cataloged in the present study), which do not have high thermoregulatory capacity (Eickwort \& Ginsberg 1980).

The Shannon diversity analysis between the sampled years, $2011\left(\mathrm{H}^{\prime}=1.89\right)$ and $2012\left(\mathrm{H}^{\prime}=1.73\right)$ did not differ statistically ( $p<0.001)$. These results can be corroborated by Sorensen's similarity index (ISS $=88.88 \%)$. The most frequent species were
Exomalopsis (Exomalopsis) analis Spinola, followed by Apis mellifera L. (table 1). Exomalopsis analis was considered the main pollinator in the studied area. This is due to three factors: 1) high frequency of flower visitation, 2) ability to vibrate the flowers for pollen collection, and 3 ) foraging activity during the entire flower development period. These characteristics fit into the standards that define an efficient pollinator, which are local abundance, ability to carry pollen and fidelity to the species visited (Lindsey 1984).

Exomalopsis analis was also the most frequent in other studies with tomato in conventional crop (Macias-Macias et al. 2009, Silva-Neto et al. 2013, Deprá et al. 2014, Santos et al. 2014, Silva-Neto et al. 2016). The high frequency of Exomalopsis analis is probably related to the fact that this species nests in soil aggregations, where in each one, several females use the same entrance (Michener 2006). Gaglianone et al. (2015) point out that this type of behavior results in a greater number of individuals in the area.

This information combined with their vibrating capacity makes this species the main tomato pollinator in this type of crop. Together with Exomalopsis analis, always mentioned in most of the studies cited with 

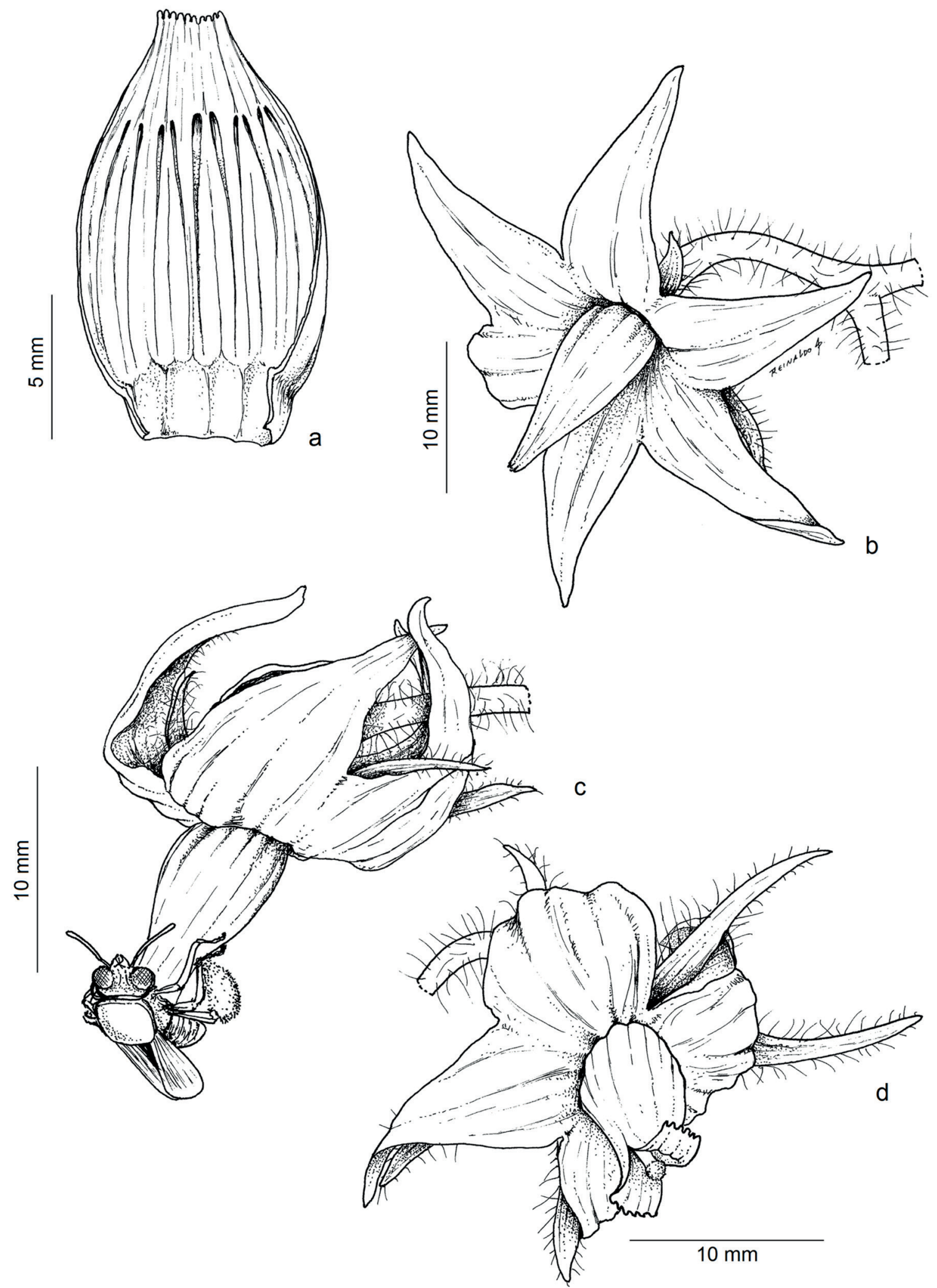

a

Figure 2. Solanum lycopersicum flowers, Fazenda Boa Vista, Guiricema, Minas Gerais State, Brazil. a. Rimose anthers. b. Detail of the flower showing anthers forming a cone-shaped structure with one pore at the apex. c. Bee positioned below the apical pore. $d$. Detail of the flower showing the cone of the anthers externally folded at the apex and exposing the stigma. Drawn by Reinaldo Pinto. 


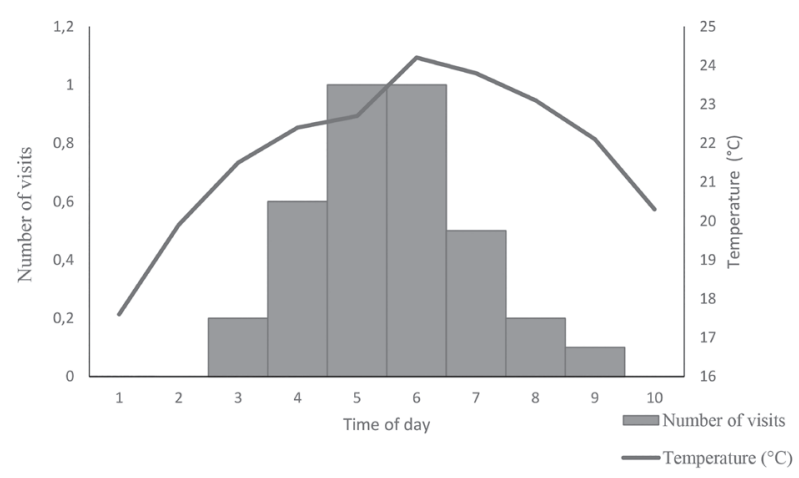

Figure 3: Average of flower visitors and temperature per hour of day in Fazenda Boa Vista, Guiricema, Minas Gerais State, Brazil.

Solanum lycopersicum, including this one, and by the vibrating habit presented, species of the genera Bombus, Augochloropsis and Pseudaugochlora could also be considered important pollinators in conventional culture.

The species Apis mellifera, Trigona spinipes Fabricius and Plebeia sp., were the only non-vibrating bees found in the area. Thus, the pollen was collected by two methods: 1) taking advantage of the remaining pollen in the flower due to the vibration of another species of bee or 2) inserting the gloss in the cone of anthers, through the apical pore, and reaching the stamens. Among the non-vibrating species, Apis mellifera and Trigona spinipes collected pollen by both methods and Plebeia sp. only by method 1 .

Apis mellifera and Trigona spinipes, because of their inability to vibrate flowers, are generally considered only robber species (Deprá et al. 2014). However, in the present study, by inserting the gloss in the anther cone to collect the pollen grains, it was observed that these bees were contaminated with them, especially on the head. When foraging on another plant, they can cross-pollinate by touching the stigma of the flower visited. Despite this, it is important to note that Trigona spinipes have damaged many tomato flowers with their jaws. This type of behavior may decrease the percentage of fruiting, causing harm to the producer (Boiça-Júnior et al. 2004).

Plebeia sp. also did not vibrate the flowers collecting the remaining pollen from them, without actually performing pollination. This species was first recorded foraging on tomato flowers and it seems that both observed visits (one each year) were only random. With a relatively small body measuring ca. 3-6 mm (Michener, 2006) and unable to effect buzz pollination, the species was considered only looter.
The behavior of Apis mellifera and Trigona spinipes is facilitated by the fact that in several Solanum lycopersicum flowers, the apical region of the anthers cone folded externally and exposed the stigma (figure 2d). Patrício et al. (2012) observed the efficiency of Apis mellifera pollinating eggplants and Amoako \& Yeboa-Gyan (1991) had already mentioned that this species could act as a pollinator in tomato flowers and other vegetables, such as eggplant and pepper.

The exposure favors the contact of this structure with the bees foraging and, therefore facilitates the action of these non-vibrating species in the pollination process. Our results were similar with others studies which verify the potential of non-vibrating species in tomato pollination, including Trigona iridipennis Smith, Apis cerana L., Apis mellifera and Paratrigona lineata Lep. (Putra \& Kinasih 2014, Santos et al. 2014).

Influence of pollinators on fruit yield and quality From the pollination tests, it was observed that in both bagged and non-bagged flowers it occurred fruit formation. However, around $40 \%$ of the fruits from bagged flowers, in both years, aborted at the beginning of development and in flowers with free access to the bees, all the fruits formed developed until reaching the harvest stage. This considerable percentage of aborted fruits is probably related to failures in the pollination process (Kinet \& Peet 2002). These results reinforce the importance of these agents to tomato crop production.

In a comparison between the fruits produced by bagged and unpackaged flowers, it was verified that the weight and the seeds number in the fruits from non-bagged flowers differed statistically between the pollination test (table 2 and 3 ). These data corroborate other studies that mention the importance of the pollinators to the production of fruits with higher quality in Solanum lycopersicum (Morandin et al. 2001, Bell et al. 2006, Hogendoorn et al. 2006, Greenleaf \& Kremen 2006). In addition, the results obtained were similar to those reported in others studies (Aldana et al. 2007, Silva-Neto et al. 2013, Bartelli \& Nogueira-Ferreira 2014, Deprá et al. 2014, Santos et al. 2014, Silva 2015).

The number of seeds produced in the fruits is directly associated with the number of pollen grains that reach the stigma and fertilize the oosphere. According to Kinet \& Peet (2002), seed quantity is associated with tomato quality and this parameter influences fruit size and weight (Nuez 2001, Alvarenga 2004, Rodríguez et al. 2005). The average weight is 
Table 2. Weight of tomatoes fruits according to different pollination tests in 2011 and 2012 in Fazenda Boa Vista, Guiricema, Minas Gerais State, Brazil.

\begin{tabular}{lcccrcrc}
\hline Year & $\begin{array}{c}\text { Pollination } \\
\text { test }\end{array}$ & $\begin{array}{c}\text { Number of } \\
\text { tomatoes }\end{array}$ & Minimum & Average & Maximum & $\begin{array}{c}\text { Standard } \\
\text { Deviation }\end{array}$ & P-value* \\
\hline \multirow{2}{*}{2011} & Open & 50 & 176.92 & 255.24 & 464.99 & 62.65 & $<0.001^{* *}$ \\
\hline \multirow{2}{*}{2012} & Self & 30 & 6.48 & 77.87 & 181.13 & 72.41 & $<0.001$ \\
\hline \multirow{2}{*}{$2011+2012$} & Open & 50 & 175.00 & 260.27 & 478.66 & 57.67 & $<$ \\
& Self & 28 & 5.50 & 58.59 & 132.77 & 37.06 & $<0.001$ \\
\hline
\end{tabular}

*According to $t$ test to indendent samples.

$* *$ Significant at $5 \%$ probability level.

Table 3. Number of seeds of tomatoes fruits according to different pollination tests in 2011 and 2012 in Fazenda Boa Vista, Guiricema, Minas Gerais State, Brazil

\begin{tabular}{lccccccc}
\hline Year & $\begin{array}{c}\text { Pollination } \\
\text { test }\end{array}$ & $\begin{array}{c}\text { Number of } \\
\text { tomatoes }\end{array}$ & Minimum & Average & Maximum & $\begin{array}{c}\text { Standard } \\
\text { Deviation }\end{array}$ & P-value* \\
\hline \multirow{2}{*}{2011} & Open & 50 & 127 & 235.08 & 386 & 62.65 & $<0.001^{* *}$ \\
\hline \multirow{2}{*}{2012} & Self & 30 & 3 & 107.30 & 271 & 72.41 & $<0.001$ \\
\hline \multirow{2}{*}{$2011+2012$} & Open & 50 & 158 & 250.74 & 388 & 57.41 & $<.35$ \\
& Self & 28 & 5 & 78.35 & 176 & 54.53 & \\
& Open & 100 & 127 & 242.91 & 388 & 60.30 & $<0.001$ \\
\hline
\end{tabular}

*According to $t$ test to indendent samples.

$* *$ Significant at $5 \%$ probability level.

associated to the source-drain relationship, that is, to the translocation capacity of photoassimilates to the fruit during the development of the plant (Peluzio et al. 1999).

Dempsey \& Boyton (1965) reported a higher mass in tomato fruits with the higher number of seeds and verified an increase in $1 \mathrm{~g}$ of dry weight in the fruits for each additional seed. The effect of seed number on fruit weight is still poorly understood, but it is likely that this correlation occurs due to the intense synthesis of hormones in seed tissues (Keulemans et al. 1996). It is believed that hormones are associated with the fruit's ability to import photoassimilates (Denis 1986). Thus, since the synthesis of these hormones in the seeds is intense, a greater number of them can increase the fruit weight.

Conservation practices for Solanum lycopersicum pollinators - Our results emphasize the importance of bee species considered pollinators in this study for the quality of fruits produced. Giannini et al. (2012) mention that studies upon strategies to conserving native bees need to be developed urgently. In the agricultural field, these strategies should contemplate the protection of these pollinators, as well as the maintenance of the productivity of cultivated species.

Studies on the biology of these pollinators are required so that management practices for these species can be drawn up (Silva-Neto et al. 2013, SilvaNeto et al. 2016). In this context, it is important to know more about the biology of Exomalopsis analis, a more frequent pollinator in tomato crop.

Despite the need for more studies on these agents, some practices adopted by the producers themselves can contribute to the maintenance of these pollinators in conventional crops, mainly related to the tomato crop:

1. Preservation of forest fragments and soil near cultivated areas - The cultivation carried out near forest fragments is beneficial, as they help maintain the guild of pollinators that contributes to agricultural production. These fragments provide varied sources of food to bees and nesting sites (Liow et al. 2001, Chacoff \& Aizen 2006, Klein et al. 2007, Kremen et al. 2007). According to Benevides et al. (2009) and Garibaldi et al. (2011), the small distance from the crops in relation to the natural areas positively 
influences the richness of floral visitors and fruit formation.

The distance from the forest fragments in relation to the growing area is important when considering the radius of flight of the bees during foraging. Bees of smaller size, like the majority found in this study (such as Apis mellifera, Exomalopsis analis, Exomalopsis fulvofasciata, Thygater analis, Trigona spinipes, Plebeia sp., Augochloropsis sp., Augochloropsis callichroa, Augochloropsis electra, Augochloropsis smithiana, Pseudaugochlora erythrogaster and Pseudaugochlora graminea), forage on a radius up to 800 meters from the nest (Gathmann \& Tscharntke 2002). Considering that there were two fragments of forests close to cultivation, bees that were probably nesting on these forest areas had a resources in the tomato blossoms.

Another point to highlight is the edaphic conditions of the area. Many species collected nest in soil (Michener 2006), such as Exomalopsis analis, Exomalopsis fulvofasciata, Augochloropsis sp., Augochloropsis callichroa, Augochloropsis electra, Augochloropsis smithiana, Pseudaugochlora erythrogaster and Pseudaugochlora graminea. Thus, soil preservation in and around growing areas is an important measure for the maintenance of the bee population(Gaglianone et al. 2015). The main measures that contribute to preserve the soil with short-cycle species plantations, such as tomato, are no-till, level planting and terraced construction (Embrapa 2003).

In light of this scenario, the tomatoes cultivation (and other olive groves) near forest area and its preservation, as well as of the soil at the planting site and its surrounding area, are forms to conserve the bee species. Consequently, these practices are also ways to increase fruit production, since the action of these pollinators contributes to increase the fruit quality.

2. Management of ruderal plant species close to cultivation - Tomato flowers do not produce nectar, so pollen is the only resource provided to bees as a floral reward (Buchmann 1983). Therefore, the presence of ruderal plant species in the vicinity of the crop or among the tomato plants which offer this resource (nectar), becomes an additional attraction to these agents (Gaglianone et al. 2015).

During the development of this study, several ruderal species were observed around the cultivation area, where several bees foraging on the tomato flowers were also observed foraging. Among the ruderal species found in the vicinity of the tomato cultivation under study are Leonorus sibiricus L. (Lamiaceae), Bidens pilosa L. and Vernonia sonchifolia (L.) DC. ex Wight (Asteraceae). These are considered by Gaglianone et al. (2015) common species around the tomato crop. The same authors mention that the management of ruderal species close to crops should be conducted carefully. This care is because some ruderal species may be viruses deposit that may affect tomatoes, or even be more attractive than tomato flowers, and displace the attraction of pollinators (Gaglianone et al. 2015).

Besides the ruderal species, near the tomato growing area, there were also passion fruit and okra crops. Both species have flowers that offer nectar and pollen as floral reward (Malerbo-Souza et al. 2008, Varassin et al. 2012). Some species of bees that forage on tomato flowers were also observed foraging on flowers of these other crops. Thus, cultivation of other olive groves in the vicinity of tomato planting can contribute to the attraction of floral visitors that can forage and pollinate both in tomato crop and in nearby crops.

3. Applications of agrochemicals at suitable times The use of agrochemicals in conventional plantation of Solanum lycopersicum is quite common and poses risks to workers and to environment (Reis-Filho et al. 2009), including to pollinators. The intense utilization of these agrochemicals is due to great amount of the pests attack the tomato (e.g. nematodes, bacteria, viruses and fungi) (Naika et al. 2006). In this sense, Fontes \& Silva (2002) emphasize that the agrochemical application in excess in the crop, also, is related with some others factors, mainly: high productivity per unit area; long period of fruit production; production in climate conditions unfavorable and use of place and soil inappropriate.

Garibaldi et al. (2014) mention that the use of pesticides can influences the richness, composition and abundance of bees. Thus, the agrochemicals applications should not be performance in the bloom period (Johnson \& Corn 2015). However, in conventional tomato crop the applications are carried during almost entire production period due the countless pests attack the plant (Naika et al. 2006). Therefore, the application of these products should be done early in the morning or in the late afternoon and early evening, during which there is no foraging of the bees (Pinheiro \& Freitas 2010).

In the crop where the present research was conducted, the applications were made in the late afternoon around 6 p.m. At that time, the bees had already finished their foraging. This method avoids the direct exposure of bees to products that at high 
concentrations may be lethal to these pollinators (Pinheiro \& Freitas 2010).

In order of minimize effect of agrochemicals to pollinators in tomato crop, besides that choose time with little foraging of the agents, others actions can be taken as for example: I) fractionate the applications (Pinheiro \& Freitas 2010), what can decrease the concentration of agrochemical that will be in contact with pollinators. II) Perform applications around the plants (utilization in crowing) to reduce the costs and impacts related about the insects (Pinheiro \& Freitas 2010). III) Avoid hours of the day with high temperatures, because in the conditions there is a great spray drift and volatilization of the pesticides (Johnson \& Corn 2015) what can increase its area of performance. IV) Use only agrochemicals with residual time below eight hours (Pinheiro \& Freitas 2010) to avoid its effects lasting to long time in the environment.

\section{Conclusions}

Exomalopsis analis was the most frequent floral visitor and considered the main pollinator of Solanum lycopersicum in the study area. Apis mellifera and Trigona spinipes, although not being vibrating bees can also act as pollinators of Solanum lycopersicum. The behavior of bees in the pollination of Solanum lycopersicum increases the productivity and quality, based on weight and number of seeds, of the fruits produced.

Studies on the biology of these bees are necessary and important to the proposition of management techniques bound to these species. Some practices conducted, mainly by the producers can help in this process as: 1) preservation of forest fragments near the plantations, as well as the preservation of the soil in the planted area and its surroundings; 2) maintenance of ruderal species of interest near the crop and planting close to other crops with flowers producing other floral resources besides pollen; and 3) applications of pesticides in a rational manner and at appropriate times.

\section{Acknowledgements}

The authors thank Dr. Fernando Amaral Silveira and Dr. Gabriel Augusto Rodrigues de Melo for identifying the bees; to the farmer José Geraldo de Oliveira for providing the area to conduct the research; Erli Antônio de Oliveira for his assistance on the fieldwork; to Reinaldo Pinto for the illustrations.

\section{Literature cited}

Aldana, J., Cure, J.R., Almanza, M.T., Vecil, D. \& Rodríguez, D. 2007. Efecto de Bombus atratus (Hymenoptera: Apidae) sobre la productividad de tomate (Lycopersicon esculentum Mill.) bajo invernadero en la Sabana de Bogotá, Colombia. Agronomía Colombiana, 25: 62-72.

Alvarenga, M.A.R. 2004. Tomate: produção em campo, em casa-de-vegetação e em hidroponia. UFLA, Lavras.

Amoako, J. \& Yeboa-Gyan, K. 1991. Insect pollination of three solanaceous vegetable crops in Ghana with special reference to the hole of African honey bee (Apis mellifera adansonii) for fruit set. Acta Horticulturae 288: 255-259.

Bartelli, B.F. \& Nogueira-Ferreira, F.H. 2014. Pollination Services Provided by Melipona quadrifasciata Lepeletier (Hymenoptera: Meliponini) in Greenhouses with Solanum lycopersicum L. (Solanaceae). Sociobiology 61: 510-516.

Bell, M.C., Spooner-Hart, R.N. \& Haigh, A.M. 2006. Pollination of Greenhouse Tomatoes by the Australian Bluebanded Bee Amegilla (Zonamegilla) holmesi (Hymenoptera: Apidae). Journal of Economic Entomology 99: 437-442.

Benevides, C.R., Gaglianone, M.C. \& Hoffmann, M. 2009. Visitantes florais do maracujá-amarelo (Passiflora edulis f. flavicarpa Deg. Passifloraceae) em áreas de cultivo com diferentes proximidades a fragmentos florestais na regiao Norte Fluminense, RJ. Revista Brasileira de Entomologia 53: 415-421.

Benton, T.G., Vickery, J.A. \& Wilson, J.D. 2003. Farmland biodiversity: is habitat heterogeneity the key? Trends in Ecology and Evolution 18: 182-188.

Boiça-Júnior, A.L., Santos, T.M. \& Passilongo, J. 2004. Trigona spinipes (Fabr.) (Hymenoptera: Apidae) em espécies de maracujazeiro: flutuação populacional, horário de visitação e danos às flores. Neotropical Entomology 33: 135-139.

Buchmann, S.L. 1983. Buzz pollination in angiosperms. In: C.E. Jones, R.J. Little (eds.). Handbook of Experimental Pollination Biology. Scientific and Academic Editions, New York.

Burril, M. \& Dietz, A. 1981. The response of honey bees to variation in solar radiation and temperature. Apidologie 12: 319-328.

Cauch, O., Quezada-Euán, J.J.C.,Macias-Macias, J.O., Reyes-Orecel, V., Medina-Peralta, S. \& ParraTabla,V. 2004. Behaviour and pollination efficiency of Nannotrigona perilampoides (Hymenoptera: Meliponini) on greenhouse tomatoes (Lycopersicon esculentum) in subtropical México. Journal of Economic Entomology 97: 475-481.

Chacoff, N.P. \& Aizen, M.A. 2006. Edge effects on flowervisiting insects in grapefruit plantations bordering premontane subtropical forest. Journal of Applied Ecology 43: 18-27. 
Climate-Data. 2016. Clima: Guiricema. Available in http://pt.climate-data.org/location/176209/ (acess in 05-XI-2016).

Del Sarto, M.C.L., Peruquetti, R.C. \& Campos, L.A.O. 2004. Polinização em ambiente protegido: uso da abelha-sem-ferrão mandaçaia na polinização do tomateiro em sistema orgânico de produção. In: R.L. Aguiar, R.J. Darezzo, D.E. Rozane, G.A.H. Aguilera, D.J.H. Silva. Cultivo em Ambiente Protegido Histórico, Biotecnologia e Perspectivas. UFV, Viçosa.

Del Sarto, M.C.L., Peruquetti, R.C. \& Campos, L.A.O. 2005. Evaluation of the Neotropical Stingless Bee Melipona quadrifasciata (Hymenoptera: Apidae) as Pollinator of Greenhouse Tomatoes. Journal of Economic Entomology 98: 260-266.

Dempsey, W.H. \& Boyton, J.E. 1965. Effect of seed number on tomato fruit size and maturity. Journal of American Society for Horticultural Science 86: 575-581.

Denis, F.G. 1986. Apple. In: S.P. Monselise. Handbook of fruit set and development. CRC Press, Boca Raton.

Deprá, M.S., Delaqua, G.C.G., Freitas, L.\& Gaglianone, M.C. 2014. Pollination deficit in open-field tomato crops (Solanum lycopersicum L., Solanaceae) in Rio de Janeiro state, southeast Brazil. Journal of Pollination Ecology 12: 1-8.

Dogterom, M.H., Matteoni, J.A. \& Plowright, R.C. 1998. Pollination of greenhouse tomatoes by the North American Bombus vosnesenskii (Hymenoptera: Apidae). Journal of Economic Entomology 91: 71-75.

Eickwort, G.C. \& Ginsberg, H.S. 1980. Foraging and mating behavior in Apoidea. Annual Review of Ecology and Systematics, 25: 421-446.

Embrapa. 2003. Práticas de conservação do solo e recuperação de áreas degradadas. Rio Branco: Embrapa Acre.

Fao (Food and Agriculture Organization of the United Nations. 2004. Conservation and management of pollinators for sustainable agriculture - the international response. In: B.M. Freitas, J.O.P. Pereira (eds.). Solitary bees: conservation, rearing and management for pollination. Fortaleza: Imprensa Universitária.

Fao (Food and Agriculture Organization of the United Nations). 2009. Crop Water Information: Tomato. Available in http://www.fao.org/nr/water/cropinfo tomato.html (acess in 14-VIII-2016).

Filgueiras, F.A.R. 2008. Novo manual de olericultura: agrotecnologia moderna na produção e comercialização de hortaliças. UFV, Viçosa.

Fontes, P.C.R. \& Silva, D.J.H. 2002. Produção de tomate de mesa. Aprenda Fácil, Viçosa.

Freitas, B.M., Imperatriz-Fonseca, V.L., Medina, L.M., Kleinert, A.M.P., Galetto, L., Nates-Parra, G. \& Quezada-Euán, J.J.G. 2009. Diversity, threats and conservation of native bees in the neotropics. Apidologie 40: 332-346.
Gaglianone, M.C., Campos, M.J.O., Franceschinelli, E., Deprá, M.S., Slva, P.N., Montagnana, P.C., Hautequestt, A.P., Morais, M.C.M. \& Campos, L.A.O. 2015. Plano de manejo para os polinizadores do tomateiro. Funbio, Rio de Janeiro.

Garibaldi, L.A., Steffan-Dewenter, I., Kremen, C., Morales, J.M., Bommarco, R., Cunningham, S.A., Carvalheiro, L.G., Chacoff, N.P., Dudenhoffer, J.H., Greenleaf, S.S., Holzschuh, A.H., Isaacs, R.,Krewenka, K., Mandelik, Y., Mayfield, M.M., Morandin, L.A., Potts, S.G., Ricketts, T.H., Szentgyorgyi, H., Viana, B.F., Westphal, C., Winfree, R. \& Klein, A.M. 2011. Stability of pollination services decreases with isolation from natural areas despite honey bee visits. Ecology Letters 14: 1-11.

Garibaldi, L.A., Carvalheiro, L.G., Leonhardt, S.D., Aizen, M.A.,Blaauw, B.R., Isaacs, R. \& Morandin, L. 2014. From research to action: enhancing crop yield through wild pollinators. Frontiers in Ecology and the Environment 12: 439-447.

Gathmann, A. \& Tscharntke, T. 2002. Foraging ranges of solitary bees. Journal of Animal Ecology 71: 757-764.

Giannini, T.C., Acosta, A.L., Garófalo, C.A., Saraiva, A.M., Alves-dos-Santos, I. \& Imperatriz-Fonseca, V.L. 2012. Pollination services at risk: Bee habitats will decrease owing to climate change in Brazil. Ecological Modelling 244: 127-131.

Greenleaf, S.S. \& Kremen, C. 2006 . Wild bee species increase tomato production and respond differently to surrounding land use in Northern California. Biological Conservation 133: 81-87.

Hein, L. 2009. The economic value of the pollination service, a review across scales. The Open Ecology Journal 2: 74-82.

Hogendoorn, K., Gross, C.L., Sedgley, M. \& Keller, M.A. 2006. Increased tomato yield through pollination by native Australian Amegilla chlorocyanea (Hymenoptera: Anthophoridae). Journal of Economic Entomology, 99: 829-833.

Holzschuh, A., Dudenhoffer, J.H. \& Tscharntke, T. 2012. Landscapes with wild bee habitats enhance pollination, fruit set and yield of sweet cherry. Biological Conservation 153: 101-107.

Imperatriz-Fonseca, V.L., Saraiva, A.M. \& Gonçalves, L. 2007. A Iniciativa Brasileira de Polinizadores e o avanço da compreensão dos avanços do papel dos polinizadores como produtores de serviços ambientais. Bioscience Journal 23: 100-106.

Johnson, R. \& Corn, M.L. 2015. Bee Health: The role of pesticides. Congressional Research Service, Washington.

Keulemans, J., Brusselle, A., Eyssen, R., Vercammen, J. \& Van Daele, G. 1996. Fruit weight in apple as influenced by seed number and pollinizer. Acta Horticulturae 42: 201-210. 
Kinet, J.M. \& Peet, M.M. 2002. Tomato. In: H.C. Wien. The physiology of vegetable crops. CABI Publishing, Wallingford.

Klein, A.M., Steffan-Dewenter, I. \& Tcharntke, T. 2003. Pollination of Coffea canephora in relation to local and regional agroforestry management. Journal of Applied Ecology 40: 837-845.

Klein, A.M., Vaissière, B.E., Cane, J.H., SteffanDewenter,I., Cunningham, A.S., Kremen, C. \& Tscharntke, T. 2007. Importance of pollinators in changing landscapes for world crops. Proceedings of the Royal Society B-Biological Sciences 274: 303-313.

Kremen, C., Williams, N.M. \& Thorp, R.W. 2002. Crop pollination from native bees at risk from agricultural intensification. Proceedings of the National Academy of Sciences 99: 16812-16816.

Lindsey, A.H. 1984. Reproductive biology of Apiaceae. I. Floral visitors to Thaspium and Zizia and their importance in pollination. American Journal of Botany, 71: 375-387.

Liow, L.H., Sodhi, N.S. \& Elmqvist, T. 2001. Bee diversity along a disturbance gradient in tropical lowland forests of south-east Asia. Journal of Applied Ecology 38: 180-192.

Macias-Macias, O., Chuc, J., Ancona-Xiu, P., Cauich, O. \& Quezada-Euán, J.J.G. 2009. Contribution of native bees and Africanized honey bees (Hymenoptera: Apoidea) to Solanaceae crop pollination in tropical México. Journal Applied Entomology 133: 456-465.

Malagodi-Braga, K.S. 2002. Estudo de agentes polinizadores em cultura de morango (Fragaria $x$ ananassa Duch. - Rosaceae). Tese de Doutorado, Universidade de São Paulo, São Paulo.

Malagodi-Braga, K.S. 2005. Abelhas: por quê manejá-las para a polinização? Mensagem Doce, n. 80, APACAME. São Paulo.

Malerbo-Souza, D.T., Toledo, V.A.A., Stuchi, A.C. \& Toledo, J.O.A. 2008. Estudo sobre a polinização do quiabeiro, Abelmoschus esculentus (L.) Moench. Acta Scientiarum 23: 1281-1285.

Michener, C.D. 2006. The bees of the world. Baltimore: The Johns Hopkins University Press.

Morandin, L.A., Laverty, T.M. \& Kevan, P.G. 2001. Effect of bumble bee (Hymenoptera: Apidae) pollination intensity on the quality of greenhouse tomatoes. Journal of Economic Entomology 94: 172-179.

Naika, S., Jeude, J.V.L., Goffau, M., Hilmi, M. \& Van Dam, B. 2006. A cultura do tomate: produção, processamento e comercialização. Fundação Agromisa, Wageningen.

Nuez, F. 2001. El cultivo del tomate. Ediciones MundiPrensa, Madrid.
Nunes-Silva, P., Hrncir, M., Venturieri, G.C.\& ImperatrizFonseca, V.L. 2010. O potencial das abelhas Melipona na polinização por vibração, considerando as características físicas da vibração. In:Anais do Encontro Sobre Abelhas, Ribeirão Preto, pp. 78-84.

Ollerton, J., Winfree, R. \& Tarrant, S. 2011. How many flowering plants are pollinated by animals? Oikos 120: 321-326.

Palma, G., Quezada-Euán, J.J.G., Reyes-Oregel, V., Meléndez, V. \& Moo-Valle, H. 2008. Production of greenhouse tomatoes (Lycopersicon esculentum) using Nannotrigona perilampoides, Bombus impatiens and mechanical vibration (Hymenoptera: Apoidea). Journal of Applied Entomology 132: 79-85.

Patrício, G.B., Grisolia, B.B., Desuó, I.C., Montagnana, P.C., Brocanell, F.G., Comig, E.G. \& Campos, M.J.O. 2012. The importance of bees for eggplant cultivation (Hymenoptera: Apidae, Andrenidae, Halictidae). Sociobiology, 59: 1037-1052.

Peluzio, J.M., Casali, V.W.D., Lopes, N.F., Miranda, G.V. \& Santos, G.R. 1999. Comportamento da fonte e do dreno em tomateiro após a poda apical acima do quarto cacho. Ciência Agrotécnica 23: 510-514.

Pinheiro, J.N. \& Freitas, B.M. 2010. Efeitos letais dos pesticidas agrícolas sobre polinizadores e perspectivas de manejo para os agroecossistemas brasileiros. Oecologia Australis 14: 266-281.

Plowright, R.C. \& Laverty, T.M. 1987. Bumblebees and crop pollination in Ontario. Proceedings of the Entomological Society of Ontario 118:155-160.

Pruta, R.E. \& Kinasih, I. 2014. Efficiency of local Indonesia honey bees (Apis cerana L.) and stingless bee (Trigona iridipennis) on tomato (Lycopersicon esculentum Mill.) pollination. Packistan Journal of Biological Science 17:86-91.

Reis-Filho, J.S., Marin, J.O.B. \& Fernandes, P.M. 2009. Os agrotóxicos na produção de tomate de mesa na região de Goianápolis, Goiás. Pesquisa Agropecuária Tropical, 39: 307-316

Rodríguez, A.F.M., Yuste, M.C.A. \& Moreno, J.L. 2005. Polinización de cultivos. Mundi-Prensa, Madrid.

Santos, A.B. \& Nascimento, F.S. 2011. Diversidade de visitantes florais e potenciais polinizadores de Solanum lycopersicum (Linnaeus) (Solanales: Solanaceae) em cultivos orgânicos e convencionais. Neotropical Biology and Conservation 6: 162-169.

Santos, A.O.R., Bartelli, B.F. \& Nogueira-Ferreira, F.H. 2014. Potential Pollinators of Tomato, Lycopersicon esculentum (Solanaceae), in Open Crops and the Effect of a Solitary Bee in Fruit Set and Quality. Journal of Economic Entomology 107: 987-994.

Santos, S.A.B., Roselino, A.C., Hrncir, M. \& Bego, L.R. 2009. Pollination of tomatoes by the stingless bee Melipona quadrifasciata and the honey bee Apis mellifera (Hymenoptera, Apidae). Genetics and Molecular Research 8: 751-757. 
Silva, P.N. 2015. Fauna de abelhas (Hymenoptera, Apoidea) em áreas de cultivo de tomateiro e o seu papel na polinização. Tese de doutorado, Universidade Federal de Viçosa, Viçosa.

Silva-Neto, C.M., Lima, F.G., Gonçalves, B.B., Bergamini, L.L., Bergamini, B.A.R., Elias, M.A.S. \& Franceschinelli, E.V. 2013. Native bees pollinate tomato flowers and increase fruit production. Journal of Pollination Ecology 11: 41-45.

Silva-Neto, C.M., Bergamini, L.L., Elias, M.A.S., Moreira, G.L., Morais, J.M., Bergamini, B.A.R. \& Franceschinelli, E.V. 2016. High species richness of native pollinators in Brazilian tomato crops. Brazilian Journal of Biology 26: ahead of print.

Velthuis, H.H.W. 2002. The historical background of the domestication of the bumble-bee, Bombus terrestris, and its introduction in agriculture. In: P.G. Kevan, V.L. Imperatriz-Fonseca. Pollinating bees: the conservation link between agriculture and nature. MMA, Brasília.
Varassin, I.G., Ximenes, B.M.S., Moreira, P.A., Zanon, M.M.F., Elbl, P., Löwenberg-Neto, P. \& Melo, G.A.R. 2012. Produção de néctar e visitas por abelhas em duas espécies cultivadas de Passiflora L. (Passifloraceae). Acta Botanica Brasilica 26: 251-255.

Vergara, C.H. \& Fonseca-Buendía, P. 2012. Pollination of greenhouse tomatoes by the Mexican bumblebee Bombus ephippiatus (Hymenoptera: Apidae). Journal Pollination Ecology 7: 27-30.

Williams, I.H., Corbet, S.A. \& Osborne, J.L. 1991. Beekeeping, wild bees and pollination in the European Community. Bee World 72: 170-180.

Yamamoto, M., Silva, C.I., Augusto, S.C., Barbosa, A.A.A. \& Oliveira, P.E. 2010. The role of bee diversity in pollination and fruit set of yellow passion fruit (Passiflora edulis forma flavicarpa, Passifloraceae) crop in Central Brazil. Apidologie 43: 515-526. 